\title{
Foreword
}

\section{Special Issue on Repealing the 8th: Irish Reproductive Activism}

\author{
Ailbhe Smyth ${ }^{1 *}$
}

Published: March 1, 2022

\section{FOREWORD}

On 26 May 2018, as the results of the referendum to repeal the 8th amendment filtered in and it became clear that 'Yes' had won, what I felt most clearly was an immense sense of relief. Relief that this huge obstacle to reproductive freedom in Ireland was finally about to be removed from the Constitution. For women in Ireland the 8th had felt, for many years like a great big piece of immovable granite, and now it was to be shattered. Along with relief came exhaustion, which after many decades of campaigning for reproductive rights, was and remains among many feminist activists, deep seated. Three years later it is only now that many of those who campaigned for repeal can take stock of what it meant to be part of a thirty-five-year, multi-generational, hard-fought battle. For me personally, of all the feminist and LGBTQ battles I have been engaged with, the campaign to repeal the 8th amendment was by far the toughest. The toll it took on many feminists, over several generations, needs to be acknowledged.

It must also be acknowledged, that even as Repeal was a major feminist win, it was but one battle in the long war to gain full reproductive rights for women and pregnant people in Ireland, and indeed, globally. It also has to be said that even when we have a 'win', as in Ireland and Argentina (two majority Catholic countries) most recently, feminist laurels can never rest easy. Time and time again, even when they seem firmly established, abortion rights can be challenged, as is happening right now, in front of our very eyes, in the United States and Poland. This fundamental right of choice is something that patriarchal, religious and conversative powers will consistently seek to undermine. While the personal toll of activism is often unrecognised, one positive of the repeal victory, was that feminist energies could now be re-focussed on other pressing and overdue issues.

Over thirty-five years, Irish women's activism had been engaged with many areas of inequality. Emerging slowly from a post-colonial, Catholic-dominated and deeply conservative State, women had to battle for rights within marriage, and the right to end marriage (that took two referendums to achieve), to change the laws on rape and domestic violence, to gain equal rights in employment, to fight for the right to self-determined sexuality, to gain broader access to contraceptives, to childcare, to real political participation and representation and a whole lot more. However, as all these battles were ongoing, we always had to return, again and again, to abortion and reproductive rights. There was no escape: the unresolved issue of abortion constantly demanded time and strategic energies, not least of which was dealing with profound structural inequalities between women, which had, and still have, to be fully and honestly recognised and addressed.

An aspect that can be overlooked however by both scholars and activists alike, is that in the decade or so following the insertion of the 8th into the constitution, Irish society was changing, and not least because of the impact of feminist work on attitudes, behaviours and the law. In 1992, a second referendum was held on abortion, and the right of women and pregnant people to information on full reproductive services abroad, and to travel to avail of these services was accepted by the electorate. Again in 2002, when the there was a second attempt to remove suicidal ideation as grounds for an abortion, the electorate refused. Both of these referendums were, in their limited way, 'wins', indicating that abortion was moving away from the terrain of morality towards a more nuanced, health-centred perspective. As Ireland slowly and often quite painfully secularised, decriminalising homosexuality in 1993, permitting the sale of contraceptives in Ireland without prescription in 1993, and finally allowing divorce in 1996, space began to open up to discuss women's rights, and the rights of minorities and marginalised groups. Reproductive rights remained a difficult subject, however, not least because the term 
'abortion' itself was scarcely ever uttered. It was called 'the substantive issue' or, in more everyday parlance, 'going to England'. It would take another two decades to end the circumlocutions and finally repeal the 8th.

Reflecting on the referendum in 2018 , many thoughts occur, to be sure. One that has struck me quite forcibly over these past three years relates to what we might call the 'outside' or international view. While the victory was headlined in the media and celebrated by feminists and abortion rights activists around the world, we must be careful not to see the Irish victory as a ready-made template for campaigns elsewhere. While it is undoubtedly a campaign to be studied and learnt from-after all, we had had ample practice here in Ireland-abortion rights campaigns always need to be context-specific. What the Irish victory has done however is give hope to those campaigning elsewhere for access to abortion or resisting the roll back of existing abortion rights. Beyond the messages of hope and possibility, what can perhaps be learned from the decades-long battle in Ireland is that giving up is never an option even when all seems hopeless, as it so often appeared to be in Ireland over the thirty-five years of struggle. The defeat in 1983 could have destroyed the feminist movement, as could the loss in the divorce referendum three years later in 1986, but after each setback, feminists regrouped and kept on fighting.

Domestically, the win in 2018 demonstrated the strength of a grassroots, inter-generational, intersectional feminist-led campaign. It had evolved out of a (re)turn to feminist activism around the turn of the twenty-first century. From about 2008 Feminist Open Forum placed abortion firmly and centrally on its agenda, as did other new feminist groups, from Irish Feminist Network to anarcho-feminist groups to local women's organisations, and indeed to the largest feminist Non-Governmental Organisation (NGO), the National Women's Council of Ireland (NCWI). By 2011/2012 the Abortion Rights Network (ARC) had come together to campaign for the introduction of free, safe and legal abortion in Ireland, north and south. In 2013 the Coalition to Repeal the 8th Amendment began to build, starting with twelve organisations and growing to over 100 members by the time of the referendum. Coalition members came from a wide range of areas, including feminist, pro-choice and human rights organisations, trade unions, student unions, medical and health organisations, NGOs, anti-racist, migrant and community groups and many others to campaigns for repeal. By the second decade of the twenty first century reproductive rights, and moves to repeal the 8 th, were firmly back on the agenda.

That it took the tragic death of a young pregnant woman, denied a necessary, lifesaving, abortion in an Irish hospital, to fully galvanise Irish society is appalling. The fact that this young woman, Savita Halappanavar, was told she could not have an abortion because she was in a Catholic country shocked and angered people. Her death, along with the ongoing revelations of the horrendous abuse meted out to women and girls in the Magdalen Laundries and Mother and Baby Homes seemed to magnify the deeply shameful way women had been treated for so long in this Catholic country. The sense of shame was very close to the emotional surface and people were mortified and embarrassed by the death of a young woman who had come to settle and work here, and to raise a family. It pulled the country up short and forced us to confront the reality of women's reproductive lives and the impact of our punitive laws. It was a moment for feminists to take the initiative, build a wide coalition, argue that the time had come to remove the 8th Amendment, so that abortion could be legalised at long last. Later, in March 2018, three big feminist-led membership organisations-the Coalition, the NWCI, and ARC-went on to form Together for Yes, the main driver of the Repeal referendum campaign.

Since the victory in May 2018, many analyses and reflections have been, and continue to be, offered on the campaign to repeal the 8th, its impact and legacies. It was grassroots and feminist-led, and remarkably focussed and coherent, although not without its underlying tensions. Some activists were not altogether satisfied with the research-based campaign messaging designed to win over the electorate and felt that some voices and stories were marginalised. While these were key areas of tension, ultimately campaigners fought side by side to make sure of victory. It is important now for feminist scholarship to look at the ways in which grassroots organisation collaborate and compromise in order to achieve rights. Repeal was a feminist win, but what type of feminist win? Who or what was included and who or what was not-and why-needs to be analysed? Reflections on both the campaign itself and the longer feminist activism which underpinned it are vital to understanding how such fundamental shifts and changes in Irish society have occurred. It is especially important to understand what these campaigns say about power structures in broader society and among feminist activists and about how other marginalised voices which emerged in the campaign are now being raised loud and clear. Feminist scholarship, such as we have here in this Special Issue, looks beyond the headlines to the nuances, the complications, and the difficult, uncomfortable questions of transformative campaigns, and provides vital analyses and reflections on them. Through these analyses we can also gain a more acute understanding of the myriad resistances of those in power, the very real inadequacy of subsequent legislation, and demonstrate a hyper-awareness of what more needs to be attended to. For now, it is perhaps a good thing to recognise that previously marginalised voices, those of migrant women, trans activists, Traveller/Mincéirí women, disabled women, women of colour, working class women and others are rightfully demanding a more inclusive, intersectional feminism in Ireland, and globally.

Repeal was undoubtedly a historic victory, and it has already made a difference to the lives of women and pregnant people seeking abortion in Ireland. But it did not, because it could not, resolve all the problems. In a very 
real sense, removing the obstacle of the 8th was about clearing the way for the hard work we are now embarked on of ensuring that everyone who needs an abortion can access it here, in Ireland. More than that, it cleared the way for us to strategise and organise for better reproductive and maternal healthcare for all, and for the achievement of sexual and reproductive justice in the widest possible sense. Go n'eiri linn!

Citation: Smyth, A. (2022). Special Issue on Repealing the 8th: Irish Reproductive Activism. Feminist Encounters: A Journal of Critical Studies in Culture and Politics, 6(1), 01. https://doi.org/10.20897/femenc/11745

Copyright (C) 2022 by Author/s and Licensed by Lectito BV, Netherlands. This is an open access article distributed under the Creative Commons Attribution License which permits unrestricted use, distribution, and reproduction in any medium, provided the original work is properly cited. 